\title{
Farming with reduced winter cropping in southern New Zealand: the risks and practicalities
}

\author{
David R. STEVENS ${ }^{1 *}$, Matt CANTON ${ }^{2}$, and Scott HARPHAM ${ }^{3}$ \\ ${ }^{1}$ Invermay Research Centre, AgResearch, Private Bag 50034 Mosgiel, New Zealand. \\ ${ }^{2}$ Pamu, Mararoa Station, Te Anau, Southland. \\ ${ }^{3}$ Pamu, 15 Allen Street, Te Aro, Wellington. \\ *Corresponding author: david.stevens@agresearch.co.nz
}

\begin{abstract}
Winter cropping practices to provide feed for livestock are being challenged by new freshwater and animal welfare regulations. Investigations to reduce reliance on winter forage crops in southern New Zealand tested farming resilience and practical on-farm low-crop wintering feeding grass to only $60 \%$ of the 13,900 breeding ewes at Mararoa Station in the Te Anau basin. Modelling climatic variation demonstrated that reducing the area of winter forage crops by $25 \%$ required increases in both nitrogen fertiliser use and supplement stockpiling and had similar variations in net earnings over a 10-year period of pasture and crop yield fluctuations. On-farm testing highlighted the need for long-term planning and active management of feed and animals. Changes to whole-farm practices were needed to incorporate activities throughout the year for significant reductions in winter forage crop use, which required active engagement and contributions of staff. Measuring pastures and animal responses provided data to inform key decision making. Any success needed staff engagement and accurate implementation from management. The team needed to be open minded, well planned and have a willingness to implement new practices and learn on the job. Forward planning, using Farmax modelling, provided a framework for implementation and provided confidence to test future reductions in winter forage crops.
\end{abstract}

Keywords: Winter crops, feed, climate, planning.

\section{Introduction}

The profitability of red meat sector farm businesses requires efficient ewe flocks producing high-quality carcases meeting market specifications. In seasonal production systems, winter feed supply is a key component to maintain stocking rate of breeding livestock to ensure that animal feed demand increases rapidly to capture the spring feed flush in a profitable lactation (Stevens et al., 2003). Winter feeding is important to meet gestation requirements, enabling the production of healthy offspring with maximum lifetime performance potential (Kenyon et al., 2011). However, the possible harm, through runoff and leaching of water contaminants, and animal welfare concerns created by high densities of animals on forage crops threaten their ability to fill the winter feed deficit (MPI 2020).

Moving from a traditional system to something new is challenging. All-grass wintering is an old concept. Research on the concept and practices needed to implement all-grass wintering were developed between the mid-1950's and 1980's (Paterson 1972, Brown and Harris 1972). However, much of this knowledge is no longer applicable for current animal production potential and farm system requirements. Changes in animal production, especially per ewe (Fennessy et al., 2016), have been recognised to facilitate both a reduction in over-wintering stock numbers and increased feed requirements (Stevens et al., 2011).

Grazing winter crops in situ, in often wet conditions, causes significant soil disruption, resulting in animals being exposed to muddy conditions (Monaghan et al., 2017). This generates potential welfare problems, in terms of animal comfort and nutrition (MPI 2020). The nutrition of the animal can be compromised due to poor utilisation of the available feed and any underallocation that results (Thompson and Stevens 2012). The development of mud can lead to soil loss and sediment and microbial loading in adjacent waterways (Monaghan et al., 2017). These conditions may be a result of all-grass wintering, but often are transitory, due to the more frequent movement of animals to fresh pasture. New approaches such as 4-day shifting in winter have been demonstrated to mitigate the impacts of group grazing on soil and pasture damage (Stevens et al., 2011)

The management team at Mararoa Station recently investigated the implementation of a change in winter feeding policy, from brassica forage crops to all-grass wintering, initially for their ewe flock. The aims were to improve animal welfare and performance and decrease environmental impacts. Questions to address included; what alternatives are there, and what are the risks and practicalities of implementing these alternatives for the red meat industry? This work examined both the potential to apply low-crop wintering in this environment and the practical implementation of a lowcrop wintering programme for a ewe flock. 


\section{Materials and Methods}

The study tested the opportunity to move from a crop to a pasture-based wintering system for the ewe flock in southern New Zealand. Climate data collected on the farm over 10 years was used to simulate feed supply and test the resilience of reducing the winter forage cropping area to $6 \%$ compared with the current status quo of approximately $8 \%$ land area. Practical implementation was tested by removing $60 \%$ of the ewe flock from the winter crop to be wintered on pasture only, while $40 \%$ remained.

Mararoa Station, a 4330 effective ha sheep, beef and deer farm operated by Pamu, is located in the Te Anau basin (45 50S; 167 97E). The region has a cool temperate summer and a prolonged cold winter, with pasture production peaking at approximately $50-60 \mathrm{~kg}$ $\mathrm{DM} / \mathrm{ha} / \mathrm{d}$ during late spring and a low of $0-5 \mathrm{~kg} \mathrm{DM} / \mathrm{ha} / \mathrm{d}$ during winter (Cossens 1990). Traditionally, the station has used an area of approximately $8 \%$, or 350 ha, for winter forage crops to bridge the feed supply deficit in winter. At the time of the study, the farm was currently stocked with 13,900 ewes, 980 cows and 4,300 hinds and their replacements. Average reproduction success was 140,82 and 83 progeny weaned per 100 dams mated for sheep, beef and deer respectively. Recorded weaning weights of progeny were 34,250 , and $59 \mathrm{~kg}$ at 100,180 and 112 days of age respectively. Numbers of progeny finished, not including those retained, were variable with approximately $70 \%, 30 \%$ and $100 \%$ sold as prime. Revenue attributed to each enterprise was approximately 50,15 and $35 \%$ for sheep, beef and deer respectively. The farmed effective area comprises 71 , 24 and 5\% cultivated, oversown and lucerne (Medicago sativa) pasture areas respectively, subdivided into 333 paddocks of approximately 12 ha each.

\section{Whole-farm modelling}

Preliminary modelling using Farmax (Marshall et al., 1991) investigated scenarios of forage crop area to determine a farm plan for the first step towards testing a less crop wintering system. A base model, which represented the Mararoa Station in 2016 (Current crop), was established, incorporated the forage crop area of 350 ha (250 and 100 ha of swedes (Brassica napus) and kale (B. oleracea), respectively). A model representing the use of reduced winter forage cropping area of 260 ha (180 and 80 ha swedes and kale respectively) was developed (Less crop) as a first step towards removing brassica cropping. The impact of climatic variation was tested by using a 10-year series of pasture and crop production cycles. Results from each single year model (July-June) were used to populate the following year to enable a contiguous time series. Hence, decisions and outcomes from one year were carried into the next. This allowed pasture, forage and animal management decisions, including sales and retentions, to flow through the model to test resilience of the scenarios of Current or Less winter cropping.

Default Farmax (Farmax Sheep, Beef and Deer (Science) version 7.2.2.60) model values for stock prices were used, as were standard values for general farm working expenses, except for the variables cropping, nitrogen fertiliser, purchased feed, feed conservation and pasture renewal. Variable expenditure for animal health and shearing were accounted for, as they changed with stock sales. The 2018-2019 financial year was used. While stock prices may vary due to climatic conditions, this was hard to predict and depended on wider (regional and national) weather conditions. Therefore, the decision was made to use standard stock prices throughout.

Pasture production over 10 years (2000-2009) from northern Southland (Li et al., 2012) were modified to match the seasonal variation of average pasture production on Mararoa Station, which were estimated from animal demand and pasture cover records within previous Farmax monitoring files. Climate records for matching years was sourced from on-farm and local weather station data. This was used to predict crop yields using accumulated growing degree days (GDD) from sowing to crop grazing. A value of $11 \mathrm{~kg} \mathrm{DM} /$ GDD was used to estimate potential yield (de Ruiter et al., 2008). This potential yield was adjusted to reflect local conditions. Estimates predicted an average yield over 10 years of $14,300 \mathrm{~kg} \mathrm{DM} / \mathrm{h}$. Average brassica yields at Mararoa were estimated to be $10,500 \mathrm{~kg} \mathrm{DM} /$ ha, so predictions for each year were adjusted by these relative proportions to reflect local conditions.

Tactical decisions made by farm management (Table 1) were documented, representing changes made as feed supply varied from targets for summer, autumn and spring deficits, as well as any spring and summer surpluses. These modifications were applied as required to match future feed supply and demand. Purchasing store stock was not considered as an option, given the constraints of current business policies for this farm. The financial outcomes from Farmax were then recorded. A general principle was to maintain both the numbers and performance of breeding stock and use trading of finishing stock as a buffer.

Relative changes in cash costs and income were used as an indicator of the resilience of wintering using a Current-crop or Less-crop systems. Cash values were used, as the interest, tax and depreciation circumstances on every farm is different. The income and expenses were analysed using REML analysis (Genstat 2017), with the 10 years of simulation ( 30 June balance date) as replicates to test for differences between the Less and Current crop scenarios. 
Developing and applying processes to enable a shift towards all-grass wintering

Application of a Less-crop wintering system was explored using 8500 ewes ( $60 \%$ of the flock) as a test case. Planning started in August 2017, 18 months ahead of the targeted starting point of February 2019. The modelling work shaped the general plan and provided an expectation of how the plan might be implemented. This provided staff with the confidence to trial the system. Staff were engaged (Table 2) in the planning

Table 1 Management decisions to alter feed supply and demand to meet primary production targets for the breeding operation and secondary targets for the finishing operation.

\begin{tabular}{ll}
\hline Scenario & Management decisions \\
\hline Summer deficit & Change lamb finishing to selling store lambs \\
& Sell trade heifers \\
& Sell trade steers \\
& Reduce ewe liveweight gain to 0 \\
& Wean calves up to 30 days earlier and sell \\
& Reduce cow liveweight gain to 0 \\
& Feed supplements on hand \\
& If feed still short by 31 March then apply $\mathrm{N}$ fertiliser to cultivated paddocks (up to 50 \\
& kg N/ha, up to whole area)
\end{tabular}

Autumn deficit

Calves sold store early

Trade heifers/steers sold early

Add nitrogen (as before)

Feed supplements on hand

Test hogget mating and grazing-off options.

Buy in grain and feed to deer

Spring deficit

Sell calves/R1 cattle

Increase supplement feeding in July-September

Change trade deer sales - bring carcase weights down and earlier, sell light animals store

Add nitrogen fertiliser (same criteria as before)

Dry hoggets to grazing

Sell early ewes with lambs at foot (if early problem)

Wean early flock (lambs to lucerne) at 65 days, sell ewes to works (1500)

Sell cast for age hinds (350) in-calf if early enough (September)

Summer/Autumn surplus

Keep more lambs to finish

Make extra silage and baleage (including lucerne)

Keep weaner deer to finish

Keep calves to finish

Remove nitrogen fertiliser use 
Table 2 The processes and changes that were made to implement a pasture-only winter-feeding system for a ewe flock in northern Southland, New Zealand.

\begin{tabular}{|c|c|c|}
\hline Processes & Original & Changes \\
\hline \multirow[t]{2}{*}{ Planning } & $\begin{array}{l}\text { Feed Budget Planned } 9 \text { Months prior to plan for } \\
\text { Crop area/allocation }\end{array}$ & $\begin{array}{l}\text { Formal planning } 18 \text { months in advance of } \\
\text { implementation }\end{array}$ \\
\hline & $\begin{array}{l}\text { Based on average DM grown of } 10-11 \text { Ton Swede } \\
\text { and } 85 \% \text { utilisation }\end{array}$ & $\begin{array}{l}\text { Modelling to investigate potential impacts } \\
\text { Trial of part of the ewe flock }(60 \%)\end{array}$ \\
\hline People & Standard hierarchy management & $\begin{array}{l}\text { Involve team in planning } \\
\text { Train team for monitoring and allocation } \\
\text { Engage in measuring success }\end{array}$ \\
\hline Stock policies & $\begin{array}{l}\text { Ewes drafted on visual condition into two lines } \\
\text { Light ewes fed separately over summer } \\
\text { Smaller flocks of mainlines (1500) fed very well. Take } \\
\text { away any real need to take light ewes off again as } \\
\text { less flock pressure. Average CS high 4+ } \\
\text { Ewes rotated behind Trade and replacement Ewe } \\
\text { Lambs. }\end{array}$ & $\begin{array}{l}\text { Ewes separated into three lines using Individual } \\
\text { condition score by hands-on physical scoring } \\
\text { Control ewe feed intake over summer using flocks of } \\
\text { approximately } 3000 \\
\text { Put condition on underweight capital stock in summer } \\
\text { Feed finishing stock better in summer } \\
\text { Potential early weaning of cows } \\
\text { Flexible lamb sales policy } \\
\text { Flexible trade cattle policy }\end{array}$ \\
\hline
\end{tabular}

Feed supply $\quad$ Cows doing most of the clean-up work.

Target making supplements when average farm cover exceeds $2500 \mathrm{~kg} \mathrm{DM} / \mathrm{ha}$ in spring and early summer to control feed surpluses

Feed supplements during winter period
Target making supplements as required to control feed surpluses

Feed supplements early to release pasture to grow in autumn

Target opening and closing paddock covers Measure pasture covers -easier than measuring crops

Plan for overall farm covers throughout summer and autumn

Use nitrogen fertiliser in autumn to fill potential feed deficits

Feed allocation On crop from 1st June to 10 September then set stocked on grass at target covers of 1500 .

Target Crop utilisation at $85 \%$ remainder of requirement coming in the form of hay in feeders

As feed requirement increases 6 week prior to Lambing allocating higher feed by not making them clean up totally and finish off with Cattle later on.

Supplement change to Lucerne baleage post scanning in multiples, hay still used in singles.

Monitoring Establishment of crop very important, till canopy closure then only bugs to monitor. $\mathrm{N}$ applied at canopy closure

Measure crops in early April.

Residual targets of $1000 \mathrm{~kg} \mathrm{DM} / \mathrm{ha}$ from February to August

Residual targets of 1200 from September to January Include $10 \%$ wastage in allocation

Rotationally graze in large flocks (3000) until planned start of lambing

Clean up poor quality feed in early autumn (before 1st May) before pregnancy requirements rise

Change residuals to allow for low quality during pregnancy if required

Measure pasture covers and residual from mid-January onwards

Use hands-on body condition scoring post-weaning, pre-mating and twice during winter

Potential crop yield deficit compensated by $\mathrm{N}$ use on autumn pasture to delay going onto crop.

Ewes drafted on visual condition post-scanning, light ewes fed on crop separately

Grazing planning Two Tooths delayed going onto crop till late June once shorn.

Match paddocks to future operations to ensure animals near facilities

In flocks of 1500 on crop then separate at scanning into birth groups, still of 1500 ewes.

Ensure operations like winter shearing are matched with feed in appropriate paddocks

Graze fast growing paddocks early to maximise early spring cover 
phase, trained in techniques to measure pasture quality and quantity and body condition scoring, and given key roles in determining the management and measuring of both livestock and pastures. Plate meters were purchased and used.

Livestock policies were changed (Table 2) depending on available feed quality and quantity to best match livestock requirements, especially in summer in the lead-up to creating an autumn surplus. Policies such as early weaning of cows and flexible selling and buying policies of trading stock were developed in case feed supply changed.

Understanding and utilising feed supply was recognised as a key practice to enable change. Making and feeding supplements were planned and executed, where possible, early to release autumn grass growth for winter stockpiling. Nitrogen fertiliser was identified as an on-going practice (Table 1) to meet pasture cover targets.

Specific targets for both pre- and post-grazing covers were set, and pasture measurement was implemented, as well as setting overall farm pasture covers at critical times (Table 2). The use of residual pasture covers was identified as key to control intake and meet animal nutrition requirements, and these varied depending on time of year. Target covers reflected the feed quality and underlying soil fertility. This varies depending on each farm circumstances and feed quality. Critical to meeting target intakes was the inclusion of wastage into the allocation of feed, rather than trying to account for it in the post-grazing residual. Controlling poor quality pastures, using ewes with a BCS $>3.5$, was targeted as a summer and autumn activity, to remove dead material from pastures during summer, rather than winter.

Measures for monitoring and controlling pasture covers was introduced in mid-January, just after weaning. A whole farm inventory was taken every two weeks using rising plate meters and sward sticks. Body condition score (BCS) was introduced at this point to identify 'at-risk' ewes and enable the development of a flock of BCS $>3.5$ to clean up pastures. Body condition scoring was used as a measure of feeding success, with liveweight used to determine feed allocation.

Specific grazing was planned to ensure that travel to and from yards for monitoring and shearing were minimised, areas for shelter after winter shearing were available and pastures most suited for early spring production and quality targeted for early winter grazing.

\section{Results}

\section{Climate variation testing}

Deficit feed supply conditions occurred in six out of ten years tested, which were observed in multiple seasons in three of those years (Table 3). Surpluses occurred in four out of ten years. One year had a spring deficit followed by a summer surplus. Swede and kale yields fluctuated between 8 and $16.3 \mathrm{t} / \mathrm{ha}$, while yields of

Table 3 Conditions of feed supply, supplement feed inventories and test scenario conditions for 10 years of scenario modelling of a northern Southland farm using either 350 or 260 ha of winter crop.

\begin{tabular}{|c|c|c|c|c|c|c|c|c|}
\hline \multirow{3}{*}{$\begin{array}{l}\text { Opening } \\
\text { balance or } \\
\text { average }\end{array}$} & \multicolumn{2}{|c|}{$\begin{array}{l}\text { Supplement inventory } \\
\text { (t DM on } 30 \text { June } \\
\text { each year) }\end{array}$} & \multicolumn{5}{|c|}{ Forage production (t DM/ha/annum) } & \multirow[t]{2}{*}{ Scenario applied from Table 1} \\
\hline & $\begin{array}{l}\text { Current } \\
\text { Crop } \\
(350 \text { ha })\end{array}$ & $\begin{array}{l}\text { Less } \\
\text { Crop } \\
(260 \text { ha })\end{array}$ & Cultivated & Oversown & Lucerne & $\begin{array}{l}\text { Crop } \\
(\mathrm{yr} 1)\end{array}$ & $\begin{array}{l}\text { Crop } \\
\text { (yr 2) }\end{array}$ & \\
\hline & 451 & 451 & 7.02 & 5.45 & 8.88 & 10.5 & 8.0 & \\
\hline Year 2000 & 1252 & 1254 & 7.64 & 6.01 & 9.77 & 10.3 & 7.9 & Summer surplus $(+23 \%)^{1}$ \\
\hline 2001 & 1315 & 832 & 6.85 & 5.37 & 9.51 & 10.3 & 7.8 & Autumn deficit (-65\%) \\
\hline 2002 & 1824 & 1166 & 7.79 & 6.13 & 8.27 & 9.5 & 7.3 & Spring surplus (+33\%) \\
\hline 2003 & 330 & 0 & 5.12 & 4.01 & 9.24 & 9.5 & 7.2 & $\begin{array}{l}\text { Late spring deficit }(-21 \%) \text {, } \\
\text { Autumn deficit }(-77 \%)\end{array}$ \\
\hline 2004 & 0 & 45 & 5.61 & 4.40 & 8.90 & 16.3 & 12.4 & $\begin{array}{l}\text { Early spring deficit }(-44 \%) \text {, } \\
\text { Summer deficit }(-43 \%)\end{array}$ \\
\hline 2005 & 3523 & 3435 & 8.36 & 6.57 & 8.79 & 11.0 & 8.4 & Summer surplus (+39\%) \\
\hline 2006 & 5140 & 4823 & 8.62 & 6.78 & 9.71 & 9.8 & 7.5 & Summer/autumn surplus (+35\%) \\
\hline 2007 & 4510 & 3676 & 7.58 & 5.96 & 7.92 & 8.0 & 6.1 & $\begin{array}{l}\text { Late spring deficit (-26\%) } \\
\text { summer surplus (+31\%) }\end{array}$ \\
\hline 2008 & 2438 & 2051 & 6.44 & 4.42 & 8.07 & 9.7 & 7.4 & Summer deficit (-24\%) \\
\hline 2009 & 683 & 2051 & 6.19 & 4.86 & 8.65 & 10.4 & 8.0 & Late spring deficit (-22\%) \\
\hline
\end{tabular}

1 Percentage variation from mean pasture growth conditions 
cultivated pasture ranged between 5.1 and $8.6 \mathrm{t} / \mathrm{ha}$. Supplementary feed inventories had a similar range when Current or Less crop systems were employed, ranging between 0 and 5,000 t.

The number of decisions made, over ten years simulation, to manage feed supply and demand totalled 79 and 70 for the Current and Less crop scenarios respectively (Table 4). Decisions regarding stock policy accounting for $36 \%$ of all decisions. Capital breeding stock were retained in every scenario. Trading stock ranged between keeping no finishing stock to keeping all finishing stock, with some decisions being quickly reversed if feed availability conditions changed between seasons and years. For example, the late spring deficit in 2007 prompted the early sale of yearling deer, yet good pasture growth in the following summer resulted in keeping all weaner deer into 2008 .

A change in $\mathrm{N}$ fertiliser use occurred in similar numbers in both scenarios (Table 4). However, $\mathrm{N}$ fertiliser was applied to 2710 ha per annum (63\% of the effective area) at a rate of $38 \mathrm{~kg} \mathrm{~N} / \mathrm{ha}$ on average in the Less crop scenarios, an increase in area of 320 ha (7\% of the effective area) and rate of $2 \mathrm{~kg} / \mathrm{ha}$ above the Current crop scenarios. This increase of $\$ 11 / \mathrm{ha}$ partially offset the cost savings of $\$ 24 /$ ha from less crop establishment (Table 5).

Changing feed supply through conservation, feeding out and buying in feed accounted for $46 \%$ of the decisions (Table 4). Costs of conserving surplus feed and purchasing supplements were, on average, similar in both scenarios. Overwintering finishing stock numbers were better maintained on the Less crop than the Current crop scenarios $(12.2 \%$ more calves and $4.5 \%$ more $\mathrm{R} 1$ deer), resulting in higher overall variable costs, such as animal health and other expenses (Table 5). Overall, total farm working expenses were lower in the Less crop scenarios, when compared with the Current crop scenarios.

Table 4 The number of times a range of tactical decisions were applied when either the current cropping (350 ha) programme was used or a less crop (260 ha) programme was used during a 10 year period.

\begin{tabular}{|c|c|c|c|c|}
\hline \multirow[b]{2}{*}{ Parameter } & \multirow[b]{2}{*}{ Current 350 ha crop average scenario } & \multirow[b]{2}{*}{ Tactical decision } & \multicolumn{2}{|c|}{ Scenario } \\
\hline & & & Current crop & Less crop \\
\hline \multirow[t]{2}{*}{$\begin{array}{l}\text { Nitrogen fertiliser } \\
\text { use }\end{array}$} & $\begin{array}{l}30 \mathrm{~kg} \mathrm{~N} / \mathrm{ha} \text { applied to } 1000 \text { ha in both } \\
\text { spring and autumn }\end{array}$ & $\begin{array}{l}\text { Apply more } \mathrm{N} \text { (up to } 50 \mathrm{~kg} \mathrm{~N} / \mathrm{ha} \\
\text { over all cultivatable land) }\end{array}$ & 4 & 6 \\
\hline & & Reduce $\mathrm{N}$ application & 4 & 4 \\
\hline Weaning policies & $\begin{array}{l}\text { Lambs early January, calves early April, } \\
\text { fawns late February }\end{array}$ & $\begin{array}{l}\text { Change weaning policy (early } \\
\text { weaning of ewes and/or cows) }\end{array}$ & 6 & 2 \\
\hline \multirow[t]{5}{*}{ Stock policy } & $\begin{array}{l}\text { Breeding/finishing sheep, with } 20 \% \\
\text { retained, } 26 \% \text { sold store and } 54 \% \text { sold } \\
\text { prime at } 4-8 \text { months old }\end{array}$ & $\begin{array}{l}\text { Sell stock (including weaned } \\
\text { lambs, weaned calves, weaned } \\
\text { fawns, ewes with lambs at foot, } \\
\text { in-calf hinds) }\end{array}$ & 14 & 8 \\
\hline & $\begin{array}{l}\text { Breeding cattle, with } 26 \% \text { retained, } 54 \% \\
\text { sold at weaning, } 20 \% \text { sold prime as } 18 \\
\text { months old }\end{array}$ & $\begin{array}{l}\text { Keep stock (alter number of } \\
\text { lambs finished and calves } \\
\text { retained to } 18 \text { months) }\end{array}$ & 7 & 9 \\
\hline & $\begin{array}{l}\text { Breeding/finishing deer, with } 26 \% \\
\text { retained, } 74 \% \text { sold prime at } 12-15 \\
\text { months old }\end{array}$ & Graze stock off (hoggets) & 2 & 2 \\
\hline & & $\begin{array}{l}\text { Reduce stock liveweight gain } \\
\text { (ewes in summer and/or cows in } \\
\text { autumn) }\end{array}$ & 8 & 4 \\
\hline & & Increase stock performance & 0 & 0 \\
\hline \multirow[t]{4}{*}{ Supplement use } & $225 \mathrm{t}$ pasture silage made and fed & $\begin{array}{l}\text { Feed more supplement (reduce } \\
\text { inventory) }\end{array}$ & 10 & 11 \\
\hline & 650 big bales lucerne made and fed & Feed less supplement & 6 & 10 \\
\hline & 700 big bales hay made and fed & Make more supplement & 4 & 4 \\
\hline & & Make less supplement & 7 & 4 \\
\hline \multirow{2}{*}{$\begin{array}{l}\text { Supplement } \\
\text { purchase }\end{array}$} & $100 \mathrm{t}$ barley purchased for deer finishing & Buy more feed & 3 & 3 \\
\hline & & Buy less feed & 4 & 3 \\
\hline
\end{tabular}


The Less crop system had a total return (Table 5) that was $\$ 29 /$ ha or $6 \%$ greater than the Current crop system $(\mathrm{P}=0.021)$. Capital value change of each system was not significantly different. The variability in both revenue (coefficient of variation $(\mathrm{CV})=11 \%$ ) and expenditure $(\mathrm{CV}=4.5 \%)$ were relatively low for both Less and Current crop scenarios. Revenue ranged between $\$ 880$ / ha and 1380/ha in both scenarios. Expenses ranged between \$560/ha and 630/ha for the Current and \$540/ ha and $\$ 635 /$ ha for the Less crop scenarios.

\section{Outcomes from implementation of a Less winter crops feeding programme}

Body condition score was identified as both an indicator of success and a driver of decision-making (Table 6). Critical to success was the training of staff, hands-on condition scoring of all animals and regular monitoring at key times. This provided the confidence to use larger flocks, confirming the success of both the feed allocation and grazing management plans.

Data were collected on the reproductive performance and mortality of ewes. Lambing percentage was $4.5 \%$ higher and ewe deaths $1.2 \%$ lower in the grass wintering system than in the Current system but was tempered by the acknowledgement that this was a single year of data collected from $60 \%$ of the flock.

Flock management approaches were tested, with flocks of up to 3000 ewes being preferred. Ewes were classified by age (two-tooth, mixed age and one-year- old-ewes), and by adequate or light condition ( $<3 \mathrm{BCS}$ ), resulting in six groups. The large flock size enabled high utilisation and suited 2 day grazing durations in each paddock. The use of the six groups with differing BCS from January onwards provided the opportunity to feed those ewes with $<3$ BCS better by grazing them in front of the main flock. This tactic meant that all ewes within an age cohort were observed when moved, which was restricted to a specific area of the farm to improve logistical efficiency.

Feed utilisation was improved during extreme weather events, and damaged pasture was grazed later if required. The flexibility of moving stock to drier parts of the farm was important in maintaining pasture utilisation and minimising soil damage.

Feed quality improved over the whole farm, especially during winter and spring, due to summer grazing management which ensured cleaning up pasture to generate high quality regrowth in autumn. Testing in late August indicated that pastures on offer were between 12.2 and $12.8 \mathrm{MJ} \mathrm{ME} / \mathrm{kg} \mathrm{DM}$.

Observations made by farm staff indicated that animal behaviour and welfare outcomes were improved (Table 6). Indicators of more consistent BCS over the whole flock and mortality in late winter both improved. Sheep behaviour was more settled and foot health was improved. General energy levels exhibited by the ewes was higher in late winter.

From the outset, engagement of staff has been

Table 5 Average returns and variable costs from 10 years for a northern Southland farm using either 350 or 260 ha of winter crop.

\begin{tabular}{|c|c|c|c|c|c|}
\hline & & $\begin{array}{c}\text { Current Crop (350 ha) } \\
\text { (\$/ha) }\end{array}$ & Less Crop (260 ha) & $P$ value & LSD \\
\hline \multirow[t]{6}{*}{ Returns } & Sheep & 606 & 612 & 0.206 & 10.85 \\
\hline & Beef & 185 & 190 & 0.794 & 41.41 \\
\hline & Deer & 400 & 408 & 0.241 & 14.27 \\
\hline & Cash & 1191 & 1210 & 0.241 & 35.03 \\
\hline & Capital value change & 6 & 1 & 0.683 & 30.37 \\
\hline & Total & 1197 & 1211 & 0.123 & 18.29 \\
\hline \multirow[t]{9}{*}{ Variable costs } & Animal health & 24 & 25 & 0.047 & 0.31 \\
\hline & Shearing & 17 & 18 & 0.158 & 0.71 \\
\hline & Forage crops & 121 & 97 & 0.001 & 1.79 \\
\hline & Conservation & 21 & 21 & 0.845 & 2.84 \\
\hline & Re grassing & 11 & 7 & & 0.00 \\
\hline & Purchased supplements & 11 & 11 & 0.876 & 3.23 \\
\hline & Nitrogen fertiliser & 34 & 45 & 0.049 & 10.15 \\
\hline & Other farm working & 354 & 356 & 0.05 & 1.74 \\
\hline & Total farm working & 595 & 579 & 0.017 & 12.05 \\
\hline \multirow[t]{2}{*}{ Net results } & Cash Return & 597 & 632 & 0.056 & 35.97 \\
\hline & Total Return & 604 & 633 & 0.021 & 23.73 \\
\hline
\end{tabular}


important to drive such changes, as they were engaged and eager to see the benefits day to day (Table 6). Growing quality grass gave a lot of satisfaction and their day-to-day work changed. Staff put up two weeks of breaks in an afternoon, without the physical limitations of working in a crop, which reduced stress and increased enjoyment of winter jobs. While planning and monitoring took longer, this was offset by lower labour requirements for stock management, and no net change in labour needs.

\section{Discussion}

Many of these processes may be recognised as current best practice. However, implementation is seldom described and often not enacted. Casey et al. (2013) documented results from 53,000 ewes over 23 high performing sheep farming enterprises in Southland and found that BCS was only practiced in $9 \%$ of cases and $12 \%$ used pregnancy scanning to identify and differentially feed triplet-bearing ewes. Average BCS was 2.36 in mid-winter - well below recommended best

Table 6 The indicators measured and outcomes observed from implementing a pasture-only winter-feeding system for a ewe flock in northern Southland, New Zealand.

\begin{tabular}{ll}
\hline Indicators & Outcomes \\
\hline Body condition score & Provides confidence in feed budgets \\
& Enables larger flocks to be used \\
& Identifies at-risk ewes for preferential feeding \\
& Identifies over-conditioned ewes for use in cleaning up \\
& Has resulted in a more even line of sheep \\
& Better control of feed as flocks have targeted nutrition
\end{tabular}

Reproductive performance
No change in scanning

Grass wintered ewes $143.6 \%$ tailing

Crop wintered ewes $139.1 \%$ tailing

Lamb weaning weight similar at $34 \mathrm{~kg}$ at 104 days of age

Grass wintered ewes $1.2 \%$ lower death rate

Splits by BCS mean larger flocks can be run

Light BCS ewes $(<3)$ run in front of the main flock

Paddock size suits 2-day shifts

Residual covers of $1000 \mathrm{~kg} \mathrm{DM} / \mathrm{ha}$ can be achieved with ewes at BCS 3+

Young and old ewes run separately

Feed utilisation

Regular moving and more area results in faster pasture recovery

Pasture can be utilised with a second graze compared to crop

Flexibility to move to drier parts of the farm in wet weather
Summer cleanout increases winter feed quality

120-day rotation in winter sets spring cover targets

High quality feed in late winter meets late pregnancy intake targets
Animal behaviour and welfare
Ewes are settled and accustomed to the feeding regimen

No mud-dags

Fewer lame ewes

Higher energy levels exhibited through movement
Team engagement

\section{Empowered to make decisions}

Make data-rich decisions

Have feedback to confirm good decisions 
practice, while $84 \%$ of farmers used winter brassica crops. These producers discovered that, when reducing reliance on crops, learning together was a significant part of the process. Planning provided the framework, and measurements provided data to understand the impact of change. This identified pathways to achieve the goals of feed supply and demand to meet animal nutrition needs. This suggested that a reliance on winter crops to automatically fill the any feed deficit led to a potential complacency in responses to overall winter feed management.

Removing the reliance on winter forage crops meant that developing new skills was key to implementing new plans. Doing the basics well, with few well understood layers, supplied data to enable fast reactions to change, and metrics for success. It was important for farm staff to understand the impact of BCS on animal productivity and welfare. Measuring pasture was a key skill that enabled successful implementation of farm feed planning.

Clear plans and measurements provided control and information to enable active management. The need to rely on pasture meant that crops, which were often not adequately monitored, were not relied on to 'fill the winter gap'. A range of management benefits could then be developed (Table 7). Key improvements included simplifying the system, timeliness of tasks and using data to inform decisions. These created other opportunities, such as targeting stock which required more feed, predicting surpluses and understanding the characteristics in individual paddocks and resources. Environmental benefits from using pasture as winter feed included reduced soil damage and related silt and nutrient losses, while redistributing nutrients over a much larger area in winter.

The welfare of the ewe flock was improved through more appropriate feed types to the demand of individual animals (Table 7). A key point was learning about the use of animal behaviour as an indicator of adequate feeding, with the ability to maintain body condition during late pregnancy, with related improvements in ewe and lamb survival (Table 6). These improvements may have been related to changing the feed type away from crops during late pregnancy, as this has been linked to lower lamb survival (Hammond et al., 2021). Feeding to appetite has been linked to lower metabolic issues with ewes in late pregnancy, including reducing the incidence of vaginal prolapse (Stevens et al., 2011)

The shift to pasture away from winter crop provided a range of rewards (Table 7) such as increased pasture growth in late winter and early spring, reduced costs, a shift in pasture towards more productive and nutritious species and the potential to capture summer surpluses with trading stock. Interventions to manage feed supply were $12 \%$ lower in the Less crop scenarios (Table 4).
This may have been related to a greater available area of pasture at critical times, such as autumn, winter and early spring. While the area involved appeared relatively trivial, it indicated the sensitivity of these environments at critical times of the year.

Results from this demonstration reflected the views of Paterson (1972). On describing key policies required to support a majority of winter feeding from pasture, Paterson, a local farmer of the time, advocated large reserves of conserved supplements, the use of winter forages of moderate yield, such as Italian ryegrass or cereals, early to mid-October lambing, training of stock to the feeding conditions, and keeping pasture under control at all times. Paterson's conditions were similar to those put in place in the current demonstration.

The similarity in results produced by the scenario development of the Current or Less crop system, and the similarity of variability across time suggested that the Less crop system was at least as robust as the current crop system. This begs the question how much further can we go with reducing the areas of high-yielding winter forage crops in this environment?

\section{Future directions}

Generally, this combination of scenario testing and onfarm trialling provided a robust first step in reducing the need for winter forage crops. The lessons learnt reflected previous experiences in the region, yet provided an adaptation for much higher performing ewe flocks. Attention to planning and on-going measurement provided a platform for agile decision-making and a means of confirming the success of those decisions.

Several questions remain unanswered and are the subject of on-going investigation by the farm team. The first is how much can be really grown and utilised? The nutrient return and change of grazing management both indicated that greater pasture growth may result. More refined feed planning increased utilisation, and removal of dead material may increase pasture production in spring (Thompson et al., 2017).

The second relates to the insurance value of winter crops. Often winter crops are not well monitored, with success only being realised when the crop is fed. The variability in crop yields was greater than that in pasture yields. This can result in a dilemma, as the farmer can only use the crop in the year it is grown, unlike the storage of conserved feed. This variability may result in lack of consistency and in a tendency to grow even more crops to compensate. This can lead to a reduced area available for grazing in early spring, and may prompt further compensation.

Maintenance of feed quality is paramount to achieving the results that are needed. Is it possible to maintain an increase in feed quality and how important is it? Controlling feed supply through appropriate 
utilisation, conservation and flexible stock trading policies can assist. With more data available, this will be readily achieved.

Pasture renewal remains an unknown. Observations to date suggested the potential for less renewal to be required. Some crops may still be required for cattle, which provide an entry point to use cropping to control weeds. The greater flexibility of grazing programmes and extra data collection can create more opportunities to renew pastures in a timely fashion, rather than in a standard progression, following crops. Different types of crops with lower yields may still be appropriate and

Table 7 Lesson learnt from implementing a pasture-only winter-feeding system for a ewe flock in northern Southland, New Zealand.

\begin{tabular}{ll}
\hline Themes & Lessons learnt \\
\hline People & Improved skills \\
& Motivation through engagement and regularly measuring results \\
& Common understanding of the processes, target outcomes and how to measure them \\
& Less time consuming \\
& Less arduous \\
& Knowing where you are and what is coming next \\
\hline
\end{tabular}

Management
Active management of feed supply and demand

Ability to see deficits and surpluses early

Stockpiling pasture as a tool

Reduces the impacts of variability

More flexibility in new grass establishment programme

More pasture area for spring grazing

Focus on right task at right time

Good data enables good decision-making

Greater understanding of the resources and their inherent differences

Better targeting of stock class to feed conditions

Simplification of the wintering systems

Integration with the range of enterprises on the farm

Environment

Less soil damage

Less runoff of nutrients

Improved nutrient distribution across the farm and within the paddock

Animal welfare

Feed demand better matched to feed supply, both amount and quality

Feed transition shocks eliminated

Ability to treat an animal as an individual

Condition on animals can be maintained in late pregnancy

Animal grazing behaviour can be used as an indicator of good feeding

Rewards

Removes the direct costs of winter cropping

Reduces wastage of both feed and livestock

Reduces animal health costs

Increases pasture growth

Improves pasture species and reduces browntop

Potential to capture summer feed surplus through trading stock

Higher body condition at lambing increases ewe and lamb survival 
provide opportunities for pasture renewal.

The modelling indicated that both the making and feeding conserved supplements was an integral part of managing feed supply. However, the requirements for feeding were much broader than just those in winter. The variability in pasture growing conditions suggested that the availability of a stockpile of conserved feed will improve the overall performance on the farm, with opportunities to utilise that feed in all seasons if required, removing current winter-only limitations of the crop system.

Other feed supply changes may be needed to further develop the resilience of the low-crop wintering system. Options, such as deferred grazing, may provide opportunities to extend utilisation of hill country. The continued development of a database concerning the performance of individual paddocks and areas of the farm will reinforce the understanding of the overall resource capability and provide opportunities to broaden the capture of value.

Many of the changes in stock policy are yet to be tested. Extra pasture growth was registered, but whether this provided a consistent outcome is unknown. Evidence from previous research suggested that this surplus will continue (Harris and Brown 1972, Stevens et al., 2011, Thompson et al., 2017). The incorporation of extra production into the overall feed supply is yet to be realised and may further change the mix and the productivity of enterprises beyond those scenarios modelled to date.

\section{ACKNOWLEDGEMENTS}

The authors would like to thank the team at Mararoa Station for their dedication to making this work, to the management of Pamu for providing the opportunity to test the system, and to MPI for funding writing the paper.

\section{REFERENCES}

Brown KR, Harris AJ. 1972. Wintering without crops - the problems involved. Proceedings of the New Zealand Grassland Association 34: 49-56. https:// doi.org/10.33584/jnzg.1972.34.1336

Casey MJ, Scandrett JS, Stevens DR. 2013. Ewe body condition: does farmer practice meet research guidelines? Proceedings of the 22nd International Grassland Congress: 1882-1883. https://www. grassland.org.nz/publications/nzgrassland_ publication_2571.pdf

Cossens GG. 1990. Pasture and lucerne production in Otago and Southland. Invermay Technical Report 21. AgResearch Ltd, Mosgiel. 21pp.

De Ruiter J, Wilson D, Maley S, Fletcher A, Fraser T, Scott W, Berryman S, Dumbleton A, Nicol W. 2009. Management practices for forage brassicas. https://pdfs.semanticscholar.org/f854/ 981d50c06975ed9b93b6566ceebadb890285.pdf. Accessed 15 March 2020.

Fennessey PF, Glennie SF, McCorkindale AB. 2016. Innovations behind the farm gate that will influence performance of hill farming. In: Thom, ER. Ed. Hill Country Symposium. Grassland Research and Practice Series 16. Dunedin, New Zealand: New Zealand Grassland Association, pp. 15-20. https:// doi.org/10.33584/rps. 16.2016.3253

Genstat 2017. GenStat for Windows 18th Edition. VSN International Ltd, Oxford.

Hammond KJ, Sandoval E, McKenzie CM, Lees S, Pacheco D, McCoard SA. 2021. The effect of a fodder beet versus ryegrass grazing regime during mid-to-late gestation twin-bearing ewes on dam and progeny performance and lamb survival. New Zealand Journal of Agricultural Research. https:// doi.org/10.1080/00288233.2021.1879175

Kenyon PR, Morris ST, Stafford KJ, West DM. 2011. Effect of ewe body condition and nutrition in late pregnancy on the performance of triplet-bearing ewes and their progeny. Animal Production Science 51: 557-564. https://doi.org/10.1071/AN10192

Li FY, Vibart R, Dynes RA, Vogeler I, Brown M. 2012. Effects of weather variability on sheep and beef farming in northern Southland, New Zealand: a modelling analysis. Proceedings of the New Zealand Grassland Association 74: 77-84. https:// doi.org/10.33584/jnzg.2012.74.2887

Marshall PR, McCall DG, Johns KL. 1991. Stockpol: a decision support model for livestock farms. Proceedings of the New Zealand Grassland Association 53: 137-140. https://doi.org/10.33584/ jnzg.1991.53.2013

Monaghan RM, Laurenson S, Dalley DE, Orchiston TS. 2017. Grazing strategies for reducing contaminant losses to water from forage crop fields grazed by cattle during winter. New Zealand Journal of Agricultural Research 60: 333-348. https://doi.org/1 $0.1080 / 00288233.2017 .1345763$

MPI 2020. Winter Grazing Taskforce. Final Report and Recommendations. https://www.agriculture.govt. $\mathrm{nz} /$ dmsdocument/38210-Winter-Grazing-TaskforceFinal-report-with-appendices-included.pdf. 33pp. Accessed June 2020

Paterson JH. 1972. Intensive farming in the Te Anau basin. Proceedings of the New Zealand Grassland Association 34: 57-62. https://doi.org/10.33584/ jnzg.1972.34.1337

Stevens DR, Baxter GS, Turner JD. 2003. Altering lamb supply: a case study of late lambing in Southern New Zealand to meet market specifications. Proceedings of the New Zealand Grassland Association 65: 6570. https://doi.org/10.33584/jnzg.2003.65.2529 
Stevens DR, Casey MJ, Scandrett JS, Baxter GS. 2011. Winter feeding - changing labour requirements and productivity. Proceedings of the New Zealand Grassland Association 73: 51-56. https://doi. org/10.33584/jnzg.2011.73.2850

Thompson BR, Stevens DR. 2012. A comparison of the intake of cows grazing swedes and kale and consequent condition score changes. Proceedings of the New Zealand Grassland Association 74: 63-68. https://doi.org/10.33584/jnzg.2012.74.2895

Thompson BR, Stevens DR, Wall AJ, Moss RA, O'Neill KT, Cox NR. 2017. Winter grazing and dead material effects on early spring pasture production. New Zealand Journal of Agricultural Research 60: 131-139. https://doi.org/10.1080/00288233.2017.12 83633 